\title{
SOME TECHNICAL PROBLEMS OF WARTIME LUMBER SUPPLY ${ }^{1}$
}

\author{
By Herbert W. Eades
}

\author{
Forest Products Laboratory, Vancouver
}

$\mathrm{T}^{\mathrm{H}}$ HE LUMBER industry of Canada has so far borne the burden of peak production unselfishly and effectively under difficult circumstances. A whole series of new problems brought about by war exigencies has been and is being met by the industry, and the Forest Products Laboratories, Department of Mines and Resources, has furnished assistance in solving the technical problems presented by wartime demands. The Vancouver laboratory, situated in what is the major lumber-producing region of the British Empire-British Columbia - has had its share of these problems, and it is chiefly of its efforts that I am qualified to speak.

Problems in the Domestic Field

According to our Timber Controller, Canada's war construction program involved the purchase of 370 million feet board measure up to Octo. ber, 1940, of which some 90 million feet board measure was purchased in British Columbia. This material was used for the construction of defence works, in plants for production of war materials, and for buildings in connection with our vast air-training plan. In this war construction program, and in our exports to the United Kingdom, our forest resources have once more proved to be a strong, if not the strongest, pillar supporting our national economy in Canada.

Probably the outstanding feat in Canada so far in the war has been the construction in something less than half the time originally contemplated, of a chain of aerodromes across Canada for training purposes under the British Commonwealth Air Training Scheme. This would have been impossible but for the availability of Canadian timber for aerodrome construction. Had structural steel, as originally proposed, been used, most of it would have had to be imported, thereby imposing what would have been a heavy strain on our exchange resources. It is recorded that in the frames for these hangars over 30 million feet board measure British Columbia Douglas fir of structural grades were utilized. The long unsupported spans necessary in these hangars were made possible by a special design of truss, and the use of split-ring connectors. All this structural framing timber was pressure-treated with zinc chloride as a combined preservative and fire retardant, and all cutting, boring for bolts, and framing was done before treatment. It is estimated that the hangars built in less than one year if placed end to end, would make a building 112 feet wide by $141 / 2$ miles long.

The provision of all this high grade material in so short a time, was, for the British Columbia lumber industry, diffcult and self-sacrificing work, the large size of the timbers creating problems in manufacture, grading, and inspection. Assistance was rendered by the laboratory in instructing graders and inspectors on the various natural defects that might be encountered in such timbers, and in suggesting improved methods of manufacture and inspec-

1. Paper presented before the Annual Meeting of Canadian Society of Forest Engineers, Victoria, B.C., Feb. 6-7-8, 1941 . 
tion. Experiments were carried out on the fire retardation provided by the zinc chloride treatment, and in investigating, under laboratory conditions, the anti-shrink effects of the zinc chloride that could be expected under summer weather conditions. This latter point is important when one considers the possible loss in structural strength if the ring-connectors and bolts should become loosened.

In this war, as in the last, Sitka spruce is definitely associated with our air supremacy. Much of the Sitka spruce aeroplane stock is now being kilindried. Suitable kiln-drying schedules for Sitka spruce have been developed, and strength tests carried out for the purpose of discovering if the schedules recommended had any weakening effect. Our studies so far indicate that they do not.

Assistance has been given in the grading and selection of aeroplane spruce and methods have been evolved which have resulted in greater economy and a higher degree of utilization than in the first Great War. At the request of the Timber Controller and the Royal Canadian Air Force, laboratory officials have acted as referees in re-inspections made necessary by cases of dispute. The use of white spruce and Engelmann spruce from the interior of British Columbia for aeroplane purposes has been investigated, and these species appear to be a promising source of material, with a satisfactory percentage of aeroplane grade recovery. An experimental carload lot has already been obtained. Eastern spruce has already been approved for this purpose.

We have been able to obtain modification of Royal Canadian Air Force and Royal Air Force specifications for various items of aeroplane construction, so as to permit the use of British Columbia woods of equivalent utility. Following various mechanical and physical tests, western birch is now accepted for wings, fusilages, and other parts of aeroplanes, and two large plants in British Columbia are turning out birch veneers for this purpose. Assistance has been promised in the grading of western birch veneer, in examining and explaining the various natural defects that may be found in this wood, and in suggesting improvements in manufacturing methods. The manufacture of plywood has increased greatly since the outbreak of war, not only for aeroplane use, but for other purposes as well. Western birch plywood sheets, 10 feet by 20 feet, 5 plies thick, with scarfed joints, and using hot-press resinbonded glue, are now being shipped to Eastern Canada for boat-building. The thinnest three-ply made from western birch is $3 / 100$ of an inch thick each ply being $1 / 100$ of an inch thick (hot-press resin bonded). This is used for wing covers. Birch veneer is also being made up to $5 / 8$ of an inch in thickness in multi-ply for aeroplane use. The strength of plywood depends primarily upon the glue binding the plies, and continual experimentation has been in progress since war broke out to find the best glues to conform with Royal Canadian Air Force specifications. Strength tests for the various Royal Canadian Air Force specifications are continually being carried out.

Investigation has been made to determine if the weight-strength ratio of multi-ply spruce after hot-press resin bonding and high compression had been raised to a greater value than the weight-strength ratio of solid spruce of the same quality. Encouraging results were obtained. 
The use of black cottonwood has been permitted for use in aeroplanes under the specifications for certain parts such as "stops," where light weight but not great strength is required.

Other examples of the substitution of British Columbia woods for other woods, under specifications developed elsewhere, are: admission of yellow cedar for use in small naval craft, such as sub-chasers, as a substitute for mahogany; use of Douglas fir for keels and keelsons in small naval craft as a substitute for white oak; and the use of British Columbia hardwood blocks for ship blocking during overhaul in drydock.

\section{PROBLEMS IN THE EXPORT FIELD}

While the volume of lumber used domestically lias been large, the volume of export lumber has been commensurate with it. I can recall that some ten years ago I wrote, in connection with a particular problem being investigated at the time, to the Admiralty, asking for information on the various uses of Douglas fir in naval craft. The reply from My Lords Commissioners was, I thought, couched in conservative terms, to say the least. It was to the effect that they had had no experience with Douglas fir in ships of H.M. Navy, but that this wood had on occasion been used for floating targets for gunnery practice, for which purpose it had given satisfaction! At that time, no doubt, the possibilities of Douglas fir were not well known for naval construction in the United Kingdom, but the picture has changed greatly in the course of ten years.

Canada is now the main source of Britain's lumber supply. In 1940, the total water-borne exports from British Columbia alone were 1,200,000,000 feet b.m., approximately the same as for 1939. Of this, more than 90 per cent went to the United Kingdom (970 million feet b.m.). The Middle East (Egypt, Palestine, and Arabia) took 17 million feet, South Africa, 84 million feet, Australia, 6 million feet, West Indies, 15 million feet, and the United States Atlantic ports, 40 million feet. Western hemlock and balsam (true fir) are being used abroad to an increasing extent for box shooks, tea chest slats, carcassing timbers, and a variety of other uses. There is a tendency in some markets to prefer balsam fir to western hemlock, and this wood, neglected in the past, or mixed in with hemlock, will soon come into its own and have its separate identity recognized. I am reminded of the salesman who having had poor luck in getting across to his customers the good qualities of western hemlock, uttered this lament "I understand some foreign guy took a drink of that tree two thousand years ago, and, by golly, it's been in the doghouse ever since." Hemlock is coming into its own, and next year many million feet will be marketed abroad. This is fortunate, because stands of timber now being cut in British Columbia are largely mixed Douglas fir, western hemlock, and western red ceriar.

The marketing of hemlock abroad has presented a number of technical problems which did not apply in the case of Douglas fir. In long voyages to foreign lands, lumber passing through the warm latitudes in the region of the Equator has every chance to stain, mould and even rot, if shipped in an unseasoned condition. This problem was not difficult to solve in the case of Douglas fir. The heartwood of this species normally has not a high moisture content, so that the stipulation in orders "shipping dry," meaning a 
drying period of 30 to 60 days, avoided most of the trouble from sap stain, mould, and decay in ocean shipments to Australia, South Africa and the United Kingdom, the last two voyages being via the Panama canal. Western hemlock, however, is naturally a much wetter wood when unseasoned, with sometimes a moisture content of around 200 per cent, based on the oven-dry weight of the wood, and a short period of air-seasoning, or even partial kilndrying, will not reduce the moisture content to a low enough figure to prevent fungal degrade in transit. Antiseptics may be used to reduce sap stain and mould, and the Vancouver laboratory has carried out experiments with known proprietary compounds to determine those most effective on British Columbia woods. We have also carried out small experimental shipments to foreign ports to determine what actually happens to unseasoned lumber on such voyages.

Owing to the length of time required to air season hemlock and the limitations of storage space in British Columbia, the alternative of kiln-drying suggests itself, but, in time of war, speed of delivery is often required, and, in addition, kiln capacity is not sufficient to take care of the situation. We are now experimenting with urea in connection with hemlock export ship. ments, particularly where large sizes are involved. These experiments are not solely as an aid to seasoning - for which purpose urea appears to offer splendid possibilities-but to find out if a treatment of urea, together with a sap stain dip, applied to unseasoned hemlock flitches before placement in the hold, would prevent fungal degrade in the course of the voyage and enable them to be used subsequently, or seasoned, as may be desired, in a warm country like South Africa without the serious checking and splitting that might be expected in unprotected, green lumber.

The normal channels of trade have been greatly disrupted by the war, and we are frequently called upon to express opinions on the merits of this or that Canadian wood as a satisfactory substitute in a certain market. We have been instrumental in this way in establishing entry into markets abroau, which may possibly be retained when the war is over. We have, for example, found a substitute for Roumanian whitewood in the Middle East market and in South Africa; we have investigated the suitability of arbutus and western yew burls and roots for pipe making, to take the place of Algerian, French and Italian briar; and we are investigating the use of British Columbia harjwoods in the manufacture of spindles and loom parts for the Shanghai and Hong Kong markets, for which Scandinavian plane has been hitherto specified.

In connection with the shipment of foodstuffs and their storage in the United Kingdom, we have carried out studies on the rusting of canned goods in wooden and fibre cases, with chief attention being paid to the effect of atmospheric conditions on the moisture content of the containers, and the effect of the moisture content of the wood on the cans stored therein. The results of this study have already been applied to the conservation and storage of wartime foodstuffs.

\section{Closer Utilization of WoOd-Waste}

While the utilization of waste in our forests and at our sawmills is a perennial headache, this problem cannot be fully solved without considering 
economic factors involved, such as available markets, cost of transportation, and the comparative costs of labour in competing sources of similar supply. As far as the manufacture of synthetic wood from waste wood is concerned, it would appear that as long as a high quality of lumber is available for general purposes, it will be used and synthetic lumber will not be required in large quantities until such time as the supply of good lumber gives out. While the ever-increasing use of plastics appears to offer a promising field for the utilization of waste wood, it must be remembered that possibly 90 per cent of the plastics used nowadays are not made from wood, but from a variety of chemicals not derived from or associated with wood. However, the use of plastics in connection with veneer layers and other parts fabricated of wood is an innovation that promises to become important before long. This development is still young, and no doubt tests will be carried out to investigate the various forms of plastic and semi-plastic aeroplane parts which have been designed.

In order to obtain maximum use of natural resources, the industry is keenly alive to the necessity of curtailing and utilizing waste wood, thus bolstering our supply of foreign exchange. There have been several develop. ments of late which promise some mitigation of this apparent economic loss. Large quantities of good tar are required by the British market, and the Scandinavian method of crude kiln charcoal burning utilizing softwoods seems the most promising method in this connection in British Columbia. We are investigating the use of sander dust, which is produced in British Columbia at the rate of many tons per day from plywood plants, as "wood flour," for use in explosives, manufacture of linoleums, and other ways. The chief stumbling block is the presence of grit in the sander dust. We have investigated the use of producer-gas in internal combustion engines, using both wood and charcoal as sources of power. There is growing interest in this feld, and if it should be found necessary to ration gasoline in Canada, as it is in Australia, there will be more interest.

\section{The Ottawa and Montreal Laboratories}

This paper may appear to you as propaganda on behalf of the Forest Products Laboratories of Canada, and particularly the Vancouver Laboratory, but what I have given you here is mainly a description of some examples of wartime technical problems as we have encountered them. However, it is of the work of the Vancouver Laboratory that I am best qualified to speak. The work of the Ottawa Laboratory covers a wider field of investigation than is possible in Vancouver because of its greater facilities and larger staff. With its divisions of wood preservation, timber mechanics, lumber seasoning, wood chemistry, timber physics, timber pathology and wood utilization, it collaborates closely with the War Supply Board, the Royal Canadian Air Force, the Department of National Defence, the National Research Council, and other government departments at Ottawa carrying on Canada's war effort. It has co-operated in providing services such as the preparation of container designs for the shipment of munitions, inspection of shipment packages, examination of commercial glues for aircraft construction and other uses, testing of aluminum and other alloys used for aircraft construction, provision of in. 
formation upon timber materials and construction, and compilation of grading rules and specifications for wood for aeroplanes and other war construction.

Among its other wartime activities may be mentioned the testing of commercial fire-retardant paints for wood. No paint has yet been found that will not break down under prolonged exposure, but some of the paints have proved effective in preventing the spread of fires of low intensity. Work is also being performed on acid-resisting paints for tanks, vats, and other wooden containers. Fire retardant treatments, usually given under pressure, were investigated. These are specified for wooden parts in many government contracts, e.g., for Bren machine gun carriers, munitions containers, and in mine sweepers and other naval craft.

Inquiry has been made into the possible utilization of Eastern spruce sawmill waste in chemical pulp. If this material can be utilized, it can supply over 15 per cent of the entire wood requirements of Canada's chemical pulp trade. A Committee of the eastern lumber and pulp industries is studying the problem further.

It appears probable that after the war there will be a demand for house construction in Europe as well as in our own country, and, with its low cost, the pre-fabricated house appears to be indicated. There are many problems concerning the design, durability, insulating factors, and general relation to health and comfort, which will have to be studied in this connection, and a start has already been made on some of these problems in collaboration with the Dominion Housing Commission.

Experiments carried out in the Pulp and Paper Division of the Labora. tories have indicated that by a very simple process the stringy sawdust formed in sawing shingle bolts can be manufactured into a good grade of insulating or building board.

Attention has been given to the nitration of special wood pulps to substitute for gun cotton, to the manufacture of mustard gas resistant papers, and to special papers for cartridge wrappers.

\section{CONCLUSION}

You will appreciate that in a short paper of this kind it is possible to deal only in a very sketchy fashion with the war research problems dealt with by the Forest Products Laboratories of Canada. If, by listening, your thoughts along these lines have been stimulated, then perhaps you may be able to suggest for the attention of our laboratories further specific problems, the solution of which would enhance the value of the contribution which the Forest Products Laboratories of Canada are making toward the war effort of our Country. 